\title{
NASR HAMID ABU ZAYD DAN GAGASAN HERMENEUTIKA DALAM TAFSIR AL- QUR'AN
}

\author{
Imam Subchi \\ UIN Syarif Hidayatullah Jakarta, Indonesia \\ E-mail: imam.subchi@gmail.com
}

\begin{abstract}
This article reviews Nasr Hamid Abu Zayd's reinterpretation of sacred texts, according to which the Qur'an does contain general ethical guidelines but does not have answers to contemporary human problems. For him, humans can do many things from outside religion. With this model of thinking, it can help overcome obstacles and freezing in Islamic thought. Abu Zaid tried to do things based on traditional religious knowledge, to adapt the findings of modern linguistics and philosophical hermeneutic theory in analyzing the Qur'an and Islamic theology.
\end{abstract}

Keywords: Nasr Hamid Abu Zayd; Al-Qur'an; Hermeneutics

Abstrak. Artikel ini mengulas reinterpretasi Nasr Hamid Abu Zayd terhadap teks-teks suci, yang menurutnya AlQur'an memang berisi pedoman etika umum namun tidak mempunyai jawaban atas problem-problem kemanusiaan kontemporer. Baginya, manusia mampu melakukan banyak hal dari luar agama. Dengan pemikiran model ini, dapat membantu mengatasi hambatan-hambatan dan kebekuan dalam pemikiran Islam. Abu Zaid berupaya melakukan hal-hal berdasarkan ilmu agama tradisional, guna mengadaptasi temuan-temuan lingusitik modern dan teori hermeneutika filosofis dalam menganalisis Al-Qur'an dan teologi Islam.

Kata Kunci: Nasr Hamid Abu Zayd; Al-Qur'an; hermeneutika

Permalink/DOI: https://doi.org/10.15408/mimbar.v36i2.14186 


\section{Pendahuluan}

Dalam sejarah pemikiran Islam terdapat banyak sarjana Muslim yang terbilang progresif dalam membuahkan pemikiran-pemikiran. Pemikiran-pemikiran mereka tidak selalu bersifat teologis transedental tetapi juga bersifat sosial kultural, bahkan terkadang pemikiran sosio-kultural mereka jauh melebih pemikiran yang bersifat teologis transedental. Tokoh-tokoh Muslim seperti Ibnu Khaldun, Ibnu Sina, Al-Farabi, dan Ibnu Rusyd adalah tokoh-tokoh Muslim yang sangat berpikiran progresif di zamannya. Pemikiran-pemikiran mereka banyak membuahkan pengetahuan modern mulai dari filsafat, matematika sampai dengan ilmu-ilmu sosial. Secara khusus pada masa Dinasti Abbasiyah, dunia Islam bahkan pernah mengalami fase di mana pemikiran-pemikiran Islam begitu berkembang. Kontak langsung dengan kebudayaan Yunani menyebabkan pemikiran Islam berkembang ke dalam bentuk yang sangat logis dan rasional. Penempatan akal manusia begitu tinggi yang bahkan disandingkan dengan Al-Qur'an. Diskursus kemudian muncul dalam meletakan posisi mana yang lebih tinggi antara akal dan Al-Qur'an. Kaum rasionalis yang kemudian dikenal sebagai Mu'tazilah ini mendominasi pemikiran dunia Islam saat itu. Salah satu teori mereka yang terkenal adalah teori yang menempatkan Al-Qur'an sebagai makhluk. Teori ini bahkan pernah dijadikan sebagai doktrin wajib umat Islam saat itu. Perdebatan tentang kedudukan Al-Qur'an ini kemudian memunculkan berbagai mazhab teologi Islam yang tetap bertahan sampai saat ini seperti Al-Asy'ari, Al-Maturidi, dan Mu’tazilah.

Setelah sekian abad tenggelam, diskursus ini kembali muncul melalui gagasan-gagasan pemikiran cendikiawan Muslim saat ini. Tokoh-tokoh seperti Amir Al-Khalli, Muhammad Arkoun dan Nasir Hamid Abu Zayd adalah tokoh-tokoh yang berhasil membawa kembali diskursus ini ke permukaan masyarakat Islam. Pemikiran mereka terbilang progressif dan berani dengan menempatkan Al-Qur'an sebagai "skrip suci” yang bersifat transedental tetapi juga sebagai produk sosial, budaya dan kemanusiaan. Nasir Hamid Abu Zayd adalah salah satu tokoh di antara tokoh-tokoh ini yang terbilang kontroversial dan mendapatkan kecaman dari masyarakat di negara. Kecaman yang berbuntut ancaman pembunuhan ini pada akhirnya membuat Abu Zayd meninggalkan negaranya sebagai "exil" dalam waktu yang cukup lama. Tentulah sangat menarik untuk membahas pemikiran-pemikiran Abu Zayd yang terbilang kontroversial untuk kemudian memperluas wacana modernitas Islam.

\section{Pembahasan}

\section{Biografi Singkat Nasr Hamid Abu Zayd}

Pemikiran dunia Islam semakin berkembang dengan diterapkannya metode hermeneutika dalam penafsiran Al-Qur'an oleh beberapa sarjana Muslim modern. Metode yang terbilang berani dan kontroversial ini mendapatkan banyak tentangan dari para pemikir Muslim lainnya. Namun demikian metode ini telah banyak memberikan kontribusi bagi modernisme pemikiran di kalangan sarjana Muslim. Salah satu tokoh pelopor penggunaan metode hermeneutika dalam penafsiran Al-Qur'an ini adalah Nasr Hamid Abu Zayd. 
Nasr Hamid Abu Zayd lahir di Quhafa, sebuah desa kecil sekitar $120 \mathrm{~km}$ dari Kairo pada tanggal 10 Juli 1943. Abu Zayd pergi memulai pendidikannya dari sebuah sekolah agama tradisional. Ia adalah seorang Qāri' dan Hafiz sejak usia muda. Pada usia 12 tahun, Abu Zayd dipenjarakan karena diduga bersimpati dengan Ikhwanul Muslimin. Dia juga dipengaruhi oleh tulisan-tulisan tokoh Muslim revolusioner Ikhwanul Muslimin, Sayyid Qutb. Namun setelah bertambah tua ia menjauh dari gagasan para Ikhwan dan Sayyid Qutb. Setelah mendapat pelatihan teknis, dia bekerja untuk Organisasi Komunikasi Nasional di Kairo. Pada saat yang sama, ia mulai belajar di Universitas Kairo. Di sana ia memperoleh gelar sarjana dalam Studi Arab pada tahun 1972, memperoleh gelar magister pada tahun 1977 dan gelar Doctor of Philosopy (PhD) pada tahun 1981 dalam bidang Studi Islam. Pada tahun 1982, ia bergabung dengan Fakultas Bahasa Arab dan Sastra di Universitas Kairo sebagai asisten profesor. Ia kemudian menjadi associate professor di sana pada tahun 1987. Selanjutnya pada tahun 1985 sampai 1989, ia bekerja sebagai dosen tamu di Osaka University Jepang (Navid Kermani, 2004).

Saat kembali ke Mesir, dia mengambil posisi sebagai Asisten Profesor dalam Studi Islam dan Retorika di Universitas Kairo. Namun pada tahun 1993, 'Abd al-Sabur Shahin, seorang profesor di Dar al-'Ulum, Kairo, secara terbuka mengecam Abu Zaid sebagai murtad. Ia secara aktif menghalangi promosi Nasr Hamid Abu Zayd menjadi profesor penuh. Segera setelah itu berbagai artikel bermunculan di media arus utama yang menuduhnya melakukan ajaran sesat. Pada bulan Juni di tahun yang sama Muhammad Samida Abu Samada mewakili berbagai kelompok Muslim konservatif di Mesir, menggugat ke pengadilan keluarga di Kairo untuk membatalkan pernikahan antara Abu Zayd dan istrinya dengan alasan kemurtadan. Hakim Abd al-Alim Musa dalam putusannya pada tanggal 14 Juni 1995 memenangkan kasus banding penggugat dan mengumumkan pembubaran pernikahannya (Hussein Ali Agarama, 2012).

Tak lama setelah putusan dikeluarkan, sekelompok profesor di Universitas al-Azhar mengeluarkan sebuah pernyataan bersama yang menyerukan eksekusi atas Nasr Hamid Abu Zayd. Organisasi Jihad Islam Mesir yang terlibat dalam pembunuhan presiden Mesir Anwar Sadat pada tahun 1981, mengeluarkan sebuah pernyataan yang mengatakan bahwa profesor tersebut harus dibunuh karena telah meninggalkan kepercayaan Muslimnya. Tapi seruan untuk kematiannya tidak hanya dilakukan oleh para pemberontak. Bahkan sebuah surat kabar yang diterbitkan oleh partai politik yang berkuasa dari rezim anti-fundamentalis sekuler, The Islamic Banner, menyatakan bahwa 'eksekusi' adalah hukuman yang tepat jika Abu Zayd tidak mau bertobat (Caryle Murphy, 2002).

Setelah mendapatkan berbagai ancaman pembunuhan di dalam negeri, pada tanggal 23 Juli 1995, Nasr Hamid Abu Zayd bersama istrinya keluar dari tanah air mereka untuk menjalani pengasingan. Mereka terbang ke Madrid, kemudian memutuskan untuk pergi dari Spanyol ke Belanda, di mana dia diundang untuk mengajar sebagai Profesor Tamu di Universitas Leiden. Dalam masa pengasingannya, Nasr Hamid Abu Zayd menulis banyak buku di antaranya al-Nașs, al-Sultah, alHaqūqah, Dawā'ir al-Khawf: Qirā’ah fì Khițāb al-Mar’ah, al-Khițāb wa-al-Ta’wīl, Hākadhā Takallama Ibn al-'Arabī, Reformation of Islamic Thought: A Critical Historical Analysis, Rethinking the Qur'an: Towards a Humanistic Hermeneutics, Voice of an Exile: Reflections on Islam. Buku-bukunya ini 
kemudian tersebar luas ke berbagai negara. Di Mesir, meskipun buku-bukunya tidak dilarang secara resmi, buku-bukunya ini banyak ditarik dari rak perpustakaan almamaternya (Caryle Murphy, 2002). Nasr Hamid kemudian dikenal sebagai pemikir Islam progresif. Ia wafat di Mesir pada tahun 2010.

\section{Nasr Hamid Abu Zayd dan Pemikiran Islam Progresif}

Kritik provokatif Abu Zayd tentang pandangan Islam yang dominan di Mesir, yang disampaikannya dalam Naqd al-khitab al-diini dan dua buku tentang status wanita, berevolusi dari konsep pemikirannya, dia menolak klaim yang menghubungkan Islam dengan satu interpretasi yang berlaku selamanya:

"Ini adalah sebuah pernyataan yang tidak disetujui dalam sejarah Islam, yaitu sejarah yang menyaksikan beragam tren, arus dan kelompok bermunculan untuk alasan sosial, ekonomi, dan politik, dan membentuk sudut pandang mereka dengan menafsirkan dan mencoba memahami teks. Apapun niat satu buku atau yang lain, desakan ini muncul dari paradigma Islam yang dan penolakan terhadap pluralitas yang sebenarnya ada dan mengarah kepada dua hasil. Pertama adalah pemahaman tunggal, yaitu pemahaman Islam yang tidak berubah, sebuah pemahaman yang tidak berpengaruh terhadap perubahan sejarah dan perbedaan antara masyarakat, belum lagi pengaruh keragaman kelompok itu mengambil bentuk dalam satu masyarakat, karena perbedaan antara kepentingan mereka. Hasil kedua adalah pemahaman yang tidak berubah ini dimiliki oleh sekelompok orang - para teolog secara luar biasa - dan bahwa anggota kelompok ini dianggap bebas dari kesombongan dan bias alami manusia” (Nasr Hamid Abu Zayd, 1992).

Abu Zayd mengutuk konsep Imamah Syiah yang menurutnya membatasi kekuasaan penafsiran dan komentar terhadap Qur'an di antara mereka. Dalam pandangan mereka, seorang Imam memiliki hak menafsirkan Al-Qur'an, bertentangan dengan doktrin Islam pada umumnya, yang menolak konsep Imamah. Hal yang sangat ditentang oleh Abu Zayd terhadap kaum Imamiyah ini karena mereka menyajikan interpretasi mereka sebagai kebenaran yang absolut dan menolak pendapat lain. Hal ini menurutnya menghilangkan perbedaan antara teks dan interpretasinya. Seperti yang dikatakan Abu Zayd:

"Semua orang berbicara tentang Islam yang tunggal, tanpa ada satupun dari mereka merasakan adanya ketidakpastian apakah ini benar pemahamannya sendiri tentang Islam, atau pemahaman terhadap teksnya." (Nasr Hamid Abu Zayd, 1992).

Selanjutnya, Abu Zayd menunjukkan bahwa dengan mengklaim tujuan Tuhan dalam teks-teks Islam mereka, para teolog berusaha masuk area sensitif, area "berbicara atas nama Tuhan", yang seharusnya dihindari dalam wacana keagamaan sepanjang sejarahnya, kecuali dalam beberapa kasus tertentu saja. Alasan seperti ini, menurut Abu Zayd pada akhirnya mengarah kepada penunjukan manusia tertentu yang mengklaim memiliki hak memonopoli pemahaman, penjelasan, komentar dan interpretasi, dan dengan demikian merasa bahwa mereka sendiri berhak berbicara tentang Tuhan. 
Di atas semua itu, monopolisasi dalam interpretasi ini berjalan paralel dengan perpanjangan relevansi sosialnya, karena teksnya atau, lebih tepatnya, interpretasi kontemporer tertentu ditentukan paling tidak oleh kepentingan politik, didefinisikan sebagai kerangka referensi komprehensif (marja 'iyya shamila): semua fenomena sosial atau fenomena fisik ditelusuri langsung kepada Tuhan, dan dari teks-Nya diharapkan bisa menjelaskan fenomena tersebut. Abu Zayd menunjukkan bahwa pemahaman Al Qur'an seperti ini sekaligus bertentangan dengan pesan Al Quran itu sendiri, karena meniadakan pentingnya alasan manusia, dan bertentangan dengan tradisi pemahaman Wahyu Tuhan di dunia Islam. Abu Zayd berpendapat:

"Ini memberikan renungan bagi kita untuk berpikir bahwa tidak satupun dari para pemikir membela penjelasannya tentang fenomena alam atau fenomena kemanusiaan dengan mendasari bahwa ini adalah "Islam". Saat salah satu sahabat Nabi Abdullah ibn 'Abbas yang menyandang gelar "Penafsir Qur'an” (tarjuman al-Qur'an), dan "cendekiawan umat” (habr al-umma) menjelaskan guntur sebagai "malaikat yang mengendarai" awan di hadapannya dengan lontaran perak dalam beberapa kompilasi hadist, tidak ada seorangpun Muslim yang menganggap hal ini sebagai sesuatu yang mutlak, suci, dan sebuah makna religius yang tidak mungkin bertentangan dengan penelitian ilmiah. Orang-orang Muslim mengerti bahwa teks ini tidak menjelaskan fenomena fisik dan fenomena manusia, namun penjelasan tersebut dibiarkan kepada aktivitas akal manusia, yang terus berkembang, untuk menemukan cakrawala kemanusiaan dan alam. Pemahaman ini sebenarnya adalah salah satu alasan terpenting untuk memberikan penghargaan terhadap jasa ulama Islam dalam bidang teknik dan sains sebagai sebuah kontribusi yang mereka berikan kepada masyarakat Eropa sebagai fondasi dalam metode eksperimen yang digunakan pada awal masa Renaisans.” (Nasr Hamid Abu Zayd, 1990).

Abu Zayd mengkritik seruan modernisasi Islami yang sering dilakukan bukan hanya dalam hukum, tapi juga sastra, seni dan pengetahuan secara umum. Menurutnya, di segala bidang budaya dan sains, Al-Qur'an dan Sunnah hendaknya menjadi otoritas hukum dan analisis, yang pada akhirnya mengarah pada dominasi segala bidang kehidupan oleh manusia yang beragama (rijal al-din) (Nasr Hamid Abu Zayd, 1992). Dia menggarisbawahi fakta bahwa meskipun kecenderungan untuk melihat Al-Quran sebagai kerangka acuan yang umum bagi semua bidang kehidupan tidak ditemukan oleh dunia Islam modern dan memang berasal dari tradisi yang panjang yang pada akarnya kembali kepada kelompok Khawarij (Nasr Hamid Abu Zayd, 1992). Namun demikian selama masa Nabi, urusan agama dan sekuler tetaplah terpisah. Ia berpendapat:

"Dari saat pertama dalam sejarah Islam dan selama periode turunnya wahyu dan pembentukan teks (tashakhul). Ada kesadaran yang tegas bahwa teks-teks agama memiliki sebuah daerah validitas atau aktivitas khusus tersendiri (majalat fáaliyyatihah), dan itu ada di daerah lain yang tunduk pada pengalaman dan akal manusia, yang tidak berhubungan dengan aktivitas teks. Hal yang sering terjadi bila disajikan dengan situasi seperti ini, pertama umat Islam bertanya kepada Nabi apakah perilakunya didasarkan pada sebuah wahyu atau pengalaman dan alasan pribadinya. Dan mereka sering memiliki pendapat berbeda dari Nabi dan menyarankan tindakan yang berbeda, ketika hal itu berhubungan dengan bidang pengalaman dan akal." (Nasr Hamid Abu Zayd, 1992). 
Kritik Abu Zayd terhadap fenomena kontemporer bukanlah sebuah sub-agenda politik dan merupakan debat akademis yang murni. Sebaliknya, studi ilmiah masa lalu sebagai alat untuk mengerti dan mengubah masa kini merupakan aspek vital karyanya. Kritiknya terhadap para teolog dan jurnalis terkemuka di Mesir dan tentangan Abu Zayd terhadap monopoli mereka akan interpretasi Teks Suci memang sangat politis. Hal ini merupakan bagian dari perjuangan oleh sejumlah intelektual terhadap pengaruh otoritas agama yang meningkat di semua bagian masyarakat, dan penerimaan yang semakin meningkat terhadap ide-ide Islam di dalam kehidupan bernegara. Abu Zayd sering menyerang kebijakan agama pemerintah dan agama resmi yang lazim menjadi wacana di Mesir, yang dibentuk oleh Universitas al-Azhar, yang disiarkan di program televisi keagamaan dan konservatif, yang sebagian besar merupakan milik negara. Dia menuduh tokoh protagonis terkemuka dalam wacana ini menyalahgunakan agama untuk kekuasaan politik dan terkadang untuk mendapatkan keuntungan. Dia juga melihat tidak ada perbedaan penting antara garis pemikiran mereka dengan kelompok oposisi ekstremis religius. Sebenarnya dia mengklaim bahwa justru media keagamaan yang dikendalikan oleh negara, dengan pengaruh besar mereka pada orang Mesir yang sebagian besar merupakan penduduk yang buta huruf, justru membuka jalan bagi kekerasan bermotif agama. Dalam pandangannya, perjuangan antara wakil Islam yang berkuasa dan mereka yang menentang rezim tersebut bukanlah konflik antara kedua Ideologi yang berbeda, hal ini adalah perjuangan yang semata-mata untuk mendapatkan kekuasaan. Karena kritiknya terhadap tren sosial dan keputusan politik yang muncul di konteks sebuah studi akademis tentang Islam, tidak mengherankan bila pada saat menerima kritiknya, para pendukung yang mereka miliki bereaksi pada tingkat teologis, dan membalas dendam dengan tuduhan bid'ah. Abu Zayd menggambarkan mekanisme ini dalam bukunya Naqd alkhitab al-dini, dalam istilah berikut: "Kami diizinkan untuk menantang aturan manusia; seseorang dapat menentangnya melalui berbagai bentuk konflik kepentingan manusia, dan menggantinya dengan sistem yang lebih adil. Akan tetapi perjuangan melawan peraturan para teolog untuk tunduk pada tuduhan ketidakpercayaan, ateisme dan bidah, umumnya digambarkan sebagai ketidaktaatan dan bid'ah melawan kuasa Tuhan". Satu tahun kemudian, ketika ia diwawancara ke Middle East Times pada tahun 1993, dia dapat membuat komentar ironis tentang dirinya sendiri bahwa: "Setiap akademis senang melihat gagasannya menjadi kenyataan” (Nasr Hamid Abu Zayd, 1992).

Alasan lainnya yang menyebabkan kemarahan terhadap Abu Zayd adalah kosakata dan metode yang dia gunakan untuk membahas Al-Quran. Sebuah buku seperti Mafhum al-nass nampaknya sejak awal tidak memiliki hubungan terhadap pembentukan dan formulasi penafsiran Al-Quran secara tradisional yang bertahan dan relatif tidak berubah selama berabad-abad. Abu Zayd tidak menolak katakata seperti ideologi, historisitas, kode dan dialektika, dan membahas wahyu Tuhan -dipengaruhi oleh Hermeneutika Barat dan linguistik- menggunakan teori model komunikasi, yang terminologinya telah diterjemahkan ke dalam bahasa Arab. Fakta bahwa isi dan temuan modelnya adalah kurang baru dan spektakuler dari model itu sendiri pun segera terlupakan. Mengingat protes yang dipicu oleh masyarakat Mesir terhadap karyanya sangat terkejut saat menemukan kenyataan itu. Tidak diragukan lagi ilmiah dan informatif, tulisannya mengandung sebagian besar penjelasan yang agak kering dari studi Al-Quran tradisional, atau analisis tentang hal ini, yang tidak mencoba mendefinisikan kembali 
Islam atau untuk menantang kepercayaan akan asal usul wahyu ilahi. Sebenarnya, pendekatan yang digunakan dalam tulisan-tulisan Abu Zayd adalah pencarian yang sama sekali baru dan dari sudut pandang Islam di Mesir, hal ini adalah ide-ide dianggap "sesat". Salah satu karakter tulisannya yang mereka perdebatkan sebagai penyerangan terhadap keyakinan agama, telah berhasil menjauhkan mereka dari diskursus akademis yang sebetulnya menjadi tujuan dari tulisannya tersebut. Selama wawancara panjang yang diterbitkan oleh jurnal al-Qahira pada bulan November 1993, Abu Zayd berulang kali menekankan bahwa dia tidak bermaksud menghadirkan sebuah konsep atau tesis yang sama sekali baru, tapi hanya untuk mengolah tema yang telah dibahas dalam studi Al-Quran klasik. Ia berpendapat bahwa ia tidak datang dengan keajaiban penemuan ilmiah (mu'jiza ma'rifiyya). Menurutnya lingkungan, iklim dan usaha untuk mempolitisasi instrumen agamalah yang membuatnya menjadi begitu. Siapapun mencari tulisan-tulisan Abu Zayd yang terutama mencari pernyataan yang bertujuan untuk mengguncang kepercayaan dan fondasi islam tentulah akan kecewa. Sebenarnya kritik ini tidak hanya untuk tulisan-tulisan yang tidak hanya "tidak Islami”, tetapi juga untuk alasan sebaliknya. Dalam sebuah artikel yang berjudul "Wacana yang menantang Fundamentalisme, tapi berbagi Akar yang sama", penulis sekuler Ali Harb menulis: "Yang benar adalah bahwa pernyataan Abu Zayd bersifat progresif dan sekuler, tapi miliknya Cara berpikirnya masih fundamentalis (usuli).” (Ali Harb, 1993).

\section{Metode Hermeneutika Tafsir Al-Qur'an Nasr Hamid Abu Zayd}

Dalam pandangan Abu Zayd, peran peradaban yang luar biasa dari Al Qur'an membuat budaya Arab menjadi "budaya teks" (hadamt al-nass). Dia melangkah lebih jauh dengan menggambarkannya sebagai budaya teks yang unggul. Budaya Arab, menurutnya, dihasilkan oleh perdebatan manusia (jadal) dengan kenyataan, dan oleh dialog (hiwar) dengan teks. (Nasr Hamid Abu Zayd, 1990). Namun untuk mendefinisikan peradaban Arab-Islam sebagai budaya teks tersebut menyiratkan bahwa itu juga merupakan budaya penafsiran (hadarat al-ta 'wil) (Nasr Hamid Abu Zayd, 1990). Bahasa Al-Qur'an menurutnya tidak dapat menjelaskan dirinya sendiri. Oleh karena itu pemahaman teks dan isinya sangat tergantung tingkat intelektualitas dan budaya pembacanya (intaj dalalatih) (Nasr Hamid Abu Zayd, 1992).

Oleh karena itu, pesan teks hanya bisa terungkap oleh para penerjemahnya. Jika Alquran mengandaikan seseorang yang menafsirkan, atau dalam istilah linguistik, "menerjemahkan'”teks dan interpretasi teks, nass dan ta 'wil, pasti tak dapat dipisahkan, satu sama lain saling terkait sebagaimana yang disampaikan Abu Zayd, penafsiran adalah "sisi lain dari teks" (al-wajh al-akhar li al-nass) (Nasr Hamid Abu Zayd, 1992). Abu Zayd dengan sengaja dan secara konsisten menggunakan istilah ta 'wil dan bukan yang lebih umum yaitu istilah tafsir, agar bisa ditekankan bagian dari kecerdasan manusia dalam tindakan penafsiran (Aql), sebagai lawan pendekatan hermeneutis yang memprioritaskan tradisi yang diceritakan (Naql)) dalam memahami teks tersebut (Nasr Hamid Abu Zayd, 1990). Dalam periode pertama teologi Muslim, ta'wil adalah terminus technicus untuknya penafsiran Alquran, sebelum menjadi dibatasi dalam bidang studi agama ke interpretasi alegoris dari Ayat-ayat yang ambigu (ayat mutasyabihat), atau bahkan didapat dari konotasi negatif saat diterjemahkan secara sewenang- 
wenang oleh pembaca Al-Qur'an. Bagi Abu Zayd, tindakan penafsiran dengan menggunakan ta'wil ini berlaku bukan sekedar penjelasan atau komentar belaka, karena tanpa itu Al Qur'an akan menjadi teks yang tidak berarti, hanya sebuah objek dengan nilai intrinsik (Nasr Hamid Abu Zayd, 1990), tanpa pesan apapun untuk umat manusia.

Bersandar kepada pendapat ahli semiotik Rusia Jurij M. Lotman, Abu Zayd mengembangkan model komunikasi teoritis di mana Qur'an - sebagaimana pesan lainnya (risala), apakah itu tanda tanda (ayat) yang bersifat verbal atau non verbal - menggambarkan hubungan komunikatif antara pengirim (mursil) dan penerima (mustaqbil), berdasarkan kepada kode (shifra) atau kepada sistem linguistik (Nasr Hamid Abu Zayd, 1995). Abu Zayd, yang menerjemahkan dua karya Lotman ke dalam bahasa Arab, mempercayai konsep teks ahli semiotik Rusia tersebut (Nasr Hamid Abu Zayd dan Siza Qasim, 1986). Lotman berpendapat bahwa seni adalah sarana komunikasi spesial, susunan bahasa yang diatur dengan makna tertentu (Gail Lenhoff dan Ronald Vroon, xxxx). Menurut premis ini, setiap karya seni disampaikan informasi melalui sistem tanda. Ini menempatkannya sebagai "teks" dalam sistem bahasa tertentu, terlepas dari kenyataan bahwa karya seni mencakup teks verbal dan non-verbal. Oleh karena itu setiap teks artistik "berperilaku sebagai sejenis organisme hidup yang memiliki umpan balik saluran ke pembaca dan dengan demikian menginstruksikannya”. Ini menyampaikan informasi yang berbeda untuk pembaca yang berbeda sebanding dengan masing-masing pemahaman seseorang (Gail Lenhoff dan Ronald Vroon, xxxx).

Kembali kepada Al Qur'an, Abu Zayd menunjukkan bahwa jika informasi yang disampaikan oleh teks bervariasi sesuai dengan pribadi pembaca serta cakrawala kultural dan sosialnya, maka esensi pesan yang disampaikan oleh Qur 'an kepada pembaca pada abad ke-21 tentulah berbeda dari informasi yang disampaikan kepada seorang Muslim di abad ketujuh, kedelapan atau kesebelas. Demikian, interpretasi apapun berdasarkan corpus eksegesis klasik, atau pada warisan Nabi dan rekan-rekannya, yang pada dasarnya adalah berdasarkan penafsiran sebelumnya. Sehingga tidak akan mungkin untuk menemukan pesan spesifik dari Alquran untuk setiap zaman (Nasr Hamid Abu Zayd, 1992).

Dalam pandangan Abu Zayd, interpretasi seorang individu tidak pernah bersifat mutlak (jahm mutlaq). Ia selalu relatif (jahm nisbi), sejak "informasi” dalam pesan ilahi bervariasi sesuai dengan siapapun yang menerimanya. Dia dengan penuh semangat mengajukan klaim bahwa penggunaan konsep teks ini, yang bersifat literal transdental atau yang hanya menggunakan interpretasi tradisional dan menekankan pada peran penafsir, bertentangan dengan Alquran dan teologi Islam (Nasr Hamid Abu Zayd, 1990). Dia berpendapat bahwa Alquran sendiri secara inheren bergantung pada interpretasi melalui akal manusia dan metode sastra yang sistematis, dengan mengutip pada ayat Al Qur'an dan kutipan dari para teolog Mu'tazili. Selain itu, dia mengacu pada disiplin Studi Alquran yang tersusun (ulum al-Qur'an), yang dibangun dalam al-Zarkashi (1392) (Badr ai-Din Muhammad ibn 'Abd Allah al-Zarkashi , 1988). atau al-Suyuti (1505) (Jalal ai-Din al-Suyuti, 1951). Untuk mendukung pandangan ini dia juga berpendapat bahwa apapun interpretasi berdasarkan pada "otoritas kaum terdahulu" (sultat al-qudama) akan menghubungkan makna teks tersebut dengan intelektual cakrawala 
dan lingkungan budaya generasi pertama Islam, atau keadaan historis zaman keemasan islam pada masa yang telah lampau (Nasr Hamid Abu Zayd, 1990).

Tiga tema utama muncul dari karya Abu Zayd: (I) untuk melacak berbagai interpretasi dan setting sejarah tunggal Teks Alquran dari hari-hari awal Islam sampai sekarang; (2) untuk menunjukkan 'keragaman interpretasi' (al-ta 'addud altawili) (Nasr Hamid Abu Zayd, 1990). yang ada dalam tradisi Islam; dan, (3) untuk menunjukkan bagaimana keragaman ini semakin teabaikan dalam sejarah umat Islam. Kekhawatiran ini kembali ke tesis Master-nya, yang memeriksa interpretasi rasional Qur'an yang diajukan kaum Mu'tazilah dan usaha mereka untuk melakukan demythologi metafora Alquran dalam konteks kondisi politik, ekonomi, dan sosial zaman ini. Dalam tesis doktoralnya, Abu Zayd mengeksplorasi penafsiran klasik Alquran lainnya, yaitu interpretasi mistis oleh Muhyi al-Din ibn 'Arabi (wafat 1240) (Nasr Hamid Abu Zayd, 1983). Refleksi Ibn 'Arabi tentang interpretasi dan pengertiannya eksistensi dan Alquran sebagai sistem komunikasi terbuka antara Tuhan dan manusia telah secara substansial membentuk pendekatan hermeneutis Abu Zayd, sebagaimana yang dia demonstrasikan pada otobiografi panjangnya.

Tulisan kritis provokatif Abu Zayd tentang teologi Islam meliput perdebatan dengan pemikiran Imam al-Syafi'i (wafat 820), dan Abu Hamid Muhammad al-Ghazali (wafat 1111), juga dengan pemikiran Muhammad Abduh (wafat tahun 1905) dan warisan salafinya (Nasr Hamid Abu Zayd, 1995). Dalam karya-karya ini Abu Zayd menunjukkan betapa spesifiknya sejarah, politik atau motivasi ideologisnya yang sebenarnya didukung oleh interpretasi tertentu yang telah tersusun dalam rentang kontemporer interpretasi yang ada. Abu Zayd mengkritik apa yang dia gambarkan sebagai "pemikiran pemikiran yang berlebihan atas tradisi", yang seringkali mengesampingkan nilai-nilai kritis, rasional, heterodoks dan kecenderungan mistik terhadap dimensi transedental saja, yang membuat sejarah budaya Islam secara politis konservatif, hanya sebagai teologi tradisional. Tujuan religius reaksioner wacana tersebut, menurut Abu Zayd, adalah untuk menyederhanakan penjelasan dalam kitab-kitab terdahulu (Nasr Hamid Abu Zayd, 1990). Ini mendukung penghafalan dan pengulangan murni tanpa meraih tingkat makna yang lebih dalam dari teks Qur'an. Muslim, menurut Abu Zayd, telah kehilangan "hubungan bebas mereka dengan Alquran", karena saat ini mereka lebih banyak diselimuti dengan aura yang transedental dan tidak dapat dipahami. Al-Qur'an menurut Abu Zayd hanya dipuja sebagai ikon suci, sedangkan pesan sebenarnya dari Qur'an lebih banyak diabaikan. Abu Zayd dengan pedas mengkritik pengurangan Al-Quran hanya menjadi objek belaka. Dia juga mengeluh pemikir Islam selama ini telah tenggelam oleh lapisan (tabaqat) penafsiran. Masing-masing penafsiran ini telah dikompromikan oleh beberapa ideologi yang pernah ada dalam sejarah Islam, menghambat semua upaya untuk menghargai teks dan peran sebenarnya dalam masyarakat Arab saat ini (Nasr Hamid Abu Zayd, 1996).

Abu Zayd berpendapat bahwa penting untuk memfokuskan kajian pada sejarah konteks wahyu saat diturunkan untuk dapat membedakan antara makna sejarah dari Qur'an (ma 'na) dan signifikansi yang lebih luas dan abadi (maghza). Karena pada dasarnya sistem linguistik (nizam lughawi) dari Qur'an sendiri berfokus pada penerima asli (mukhatabun), yaitu, orang-orang yang awalnya 
dialamatkan oleh Qur'an. Sebuah kesadaran akan historisitas teks sangat penting agar kita mampu mengerti pesan Qur'an untuk saat ini (Nasr Hamid Abu Zayd, 1990).

Dengan demikian, Abu Zayd berpendapat bahwa wahyu itu menyesuaikan diri dengan cakrawala linguistik dan intelektual dari orang-orang yang pertama dituju oleh Qur'an untuk mengubah kenyataan dan keadaan mereka. Qur'an kemudian mewujudkan hal tersebut. Ini menyiratkan wahyu memiliki beberapa hubungan - meskipun yang negatif di pengertian dialektik terhadap kenyataan. Abu Zayd menyoroti 'hubungan dialektis' ('alaqa jadaliyya) (Nasr Hamid Abu Zayd, 1990). yang ada antara Alquran dan realitas dalam banyak aspek sejarah wahyu. Sebuah contoh muncul dalam cara berhubungan dengan etika, spiritual, dan konsep khusus ideologis era pra-Islam agar bisa disematkan ini dalam kredo monoteistik dan sistem nilai yang didasarkan pada persamaan manusia. Dia menggambarkan bagaimana wahyu bereaksi terhadap peristiwa sejarah spesifik, selain perubahan umum aspek sosial dan politik umum yang sudah berlangsung, bahkan sebelum kedatangan Islam. Abu Zayd juga membahas panjang lebar sejauh mana Studi Alquran klasik (ulum al-Qur'an) dengan beberapa disiplin ilmu seperti asbab al-nuzul dan al-nasikh wal-mansukh berasal dari gagasan teks Alquran yang mengambil dimensi historis dari sejarah turunnya wahyu. Sebagai seorang sarjana dari studi sastra, fokusnya sendiri, secara alami, ada pada bahasa wahyu. Sementara itu dia menganalisis norma linguistik dan metafora Alquran yang diambil dari realitas sosial dan aturan sastra dari tempat dan waktu untuk kemudian direkonstruksi dalam sebuah bentuk bahasa yang sampai sekarang tidak diketahui. Dia memulai dari asumsi yang lebih luas, terinspirasi langsung oleh gagasan Toshihiko Izutsu (Toshihko Izutsu, 1980). Dengan mentransmisikan Alquran dalam bahasa Arab, Tuhan menurut Abu Zayd telah mengadopsi sebuah bahasa manusia dan budaya yang telah menghasilkan bahasa ini. Oleh karena Abu Zayd berpendapat, Qur'an, pada dasarnya adalah sebuah produk dari budaya tertentu (muntaj thaqafi) (Nasr Hamid Abu Zayd, 1990).

Tuhan menurut Abu Zayd memilih bahasa Arab untuk berkomunikasi dengan manusia untuk menguraikan pesan-Nya, manusia harus menganalisa ucapan-Nya dengan menggunakan metode dan aturan yang sama dengan yang diterapkan pada pidato verbal lainnya. Karena, menurut Abu Zayd, "tindakan ilahi" (al-fi' l al-ilahi) di dunia berlangsung dalam ruang dan waktu, yaitu hal itu terjadi dalam kerangka hukum dunia ini. Dia menambahkan bahwa keengganan untuk menerapkan secara meluas penggunaan akal manusia dalam memahami kalam Ilahi berawal dari anggapan bahwa hubungan antara Tuhan dan manusia didasarkan pada pemisahan, yang bahkan saling bertentangan dan berlawanan, sebuah pandangan yang umumnya dianut oleh para teolog Ash 'ari (Nasr Hamid Abu Zayd, 1992).

Bagaimanapun menurut Abu Zayd pemisahan antara Tuhan dan manusia gagal untuk mengenali sebuah kebenaran yang amat penting, yang dikonfirmasikan oleh Wahyu Ilahi Sendiri saat Ia diturunkan (Tanzil). Tanzil yang berarti sesuatu yang mengikat, dan wahyu adalah sebuah kalam yang melaluinya Tuhan dan manusia terikat satu sama lain. Dengan kata lain saat kalam (yang menunjukkan jalan Tuhan) turun dengan memanfaatkan sarana bahasa manusia, terlepas dari Kemahatahuan Tuhan, Kesempurnaan, Kekuatan, dan Hikmat-Nya, maka akal manusia akan menafsirkan kalam Ilahi 
tersebut, terlepas dari semua ketidaktahuan, ketidaksempurnaan, dan hasrat manusia (Nasr Hamid Abu Zayd, 1992).

Setelah menetapkan bahwa ada hubungan kausal antara teks dan penafsir, bahkan dalam kasus teks murni faktual, Abu Zayd menunjukkan betapa kompleks hubungan ini dalam kasus teks sastra, yang ia sebut sebagai al-nusus almumtaza (Nasr Hamid Abu Zayd, 1990). Dia mengutip karya Shakespeare sebagai contoh struktur linguistik yang sangat padat (mukaththafa) dari teks-teks ini, yang memungkinkan untuk menyampaikan secara maksimal dan pada saat bersamaan, variabilitas informasi. Ini juga berlaku untuk Quran, yang mukjizatnya sering dilacak di dalam struktur sastranya (Nasr Hamid Abu Zayd, 1990). Abu Zayd menunjukkan bahwa meskipun bahasa Qur'an 'tidak menyimpang dari sistem bahasa yang umum, Qur'an menciptakan kode sendiri, yang merekonstruksi elemen asli sistem semantik (Nasr Hamid Abu Zayd, 1992). Dia berpendapat bahwa struktur bahasa Qur'an sangat kompleks yang membedakannya dari bahasa alam. Dengan demikian berfluktuasi antara tingkat bahasa yang berbeda, antara transmisi murni "informasi" (i 'lam), dan bahasa "sastra" padat, yang menghasilkan mekanisme spesifik masing-masing' (Nasr Hamid Abu Zayd, 1990). Alat-alat studi sastra kemudian diperlukan untuk menganalisa 'mekanisme spesifik' sastra bahasa ini (lugha adabiyya): ini termasuk hermeneutika, sastra kritik, semantik, linguistik dan sains linguistik. Abu Zayd menganjurkan simbiosis studi Qui'an dan sastra. Perdebatan menurutnya hanya sebuah interpretasi yang memperhitungkan spesifikasinya. Mekanisme linguistik mampu menganalisa Alquran, mengartikan kodenya, dan menguraikan pesan bahwa Alquran berisi pesan untuk masyarakat sekarang. Dengan melakukan itu, penafsiran semacam itu melampaui makna historis Alquran untuk masyarakat Arab pada saat pewahyuannya.

Abu Zayd menyoroti keterkaitan gagasannya dengan pendapat Amin al-Khuli karena ia menjadikan Amin al-Khulli sebagai sumber referensi dari bangsa Mesir sendiri, tapi ia juga tidak menyembunyikan fakta bahwa teorinya terbentuk melalui pertemuan dan diskusi dengan penulis dari berbagai waktu dan konteks, termasuk Ahli tata bahasa Iran Sibawayhi (wafat 800), sarjana Islam Jepang Toshihiko Izutsu, yang memperkenalkan bahasa analitis metode untuk studi Islam, dan filsuf Jerman dan ahli teori hermeneutika, Hans-Georg Gadamer, penulis karya berpengaruh Wahrheit und Methode. Beberapa diskusi ini didokumentasikan dalam bukunya Ishkaliyyat al-qira'a wa aliyyat alta 'wil, yang merupakan kompilasi bahasa linguistik dan sastra utama artikelnya. Pekerjaannya mencakup pengantar Hermeneutika filosofis Eropa, yang pertama diterbitkan pada awal 1981, dan merupakan salah satu penelitian yang komprehensif tentang topik ini dalam bahasa Arab. Penekanan pada Hermeneutika Gadamer menghubungkan Abu Zayd secara khusus ke Teolog Iran Mohamad Mojtahed Shabestari, tampaknya untuk menunjukkan pada saat yang bersamaan tren yang lebih luas dalam pemikiran Islam kontemporer. Relevansi dikaitkan dengan hermeneutika untuk Penafsiran tulisantulisan keagamaan sebagian disebabkan oleh kenyataan bahwa, berbeda dengan metode analitis linguistik dan positivistik, hermeneutik menekankan subjektivitas dari segala jenis pengertian dari teks. Dalam hermeneutika filosofis, dimulai secara substansial oleh teolog dan filsuf Friedrich Schleiermacher (wafat 1834), subjek kognitif umumnya mencerminkan keadaan pribadinya. Hal ini didasarkan pada 
prinsip idealis bahwa subjek sangat berperan dalam membentuk dunia dan pengetahuan itu tidak pernah mencerminkan kenyataan yang independen dari subyek. Jika diterapkan pada Al-Qur'an, ini berarti bahwa ia tidak memiliki “makna yang objektif” yang dapat diakses oleh individu (atau teolog). Ini juga menyiratkan bahwa, tidak seperti empirisme logis, tidak ada perbedaan ilmiah yang bersifat kaku antara subjek (interpreter) dan objek (teks). Sebaliknya, setiap interpretasi adalah hasil dari hubungan tertentu antara teks dan penerjemahnya, dan mencerminkan keunikan hubungan ini. Karena itu tidak mungkin identik dengan interpretasi dari satu era dengan era lain atau dengan konteks sosial budayanya. Pendekatan yang berfokus pada subjek ini sangatlah banyak dipakai dalam menjelaskan perkembangan pemikiran ini di seluruh dunia Islam untuk mencari satu-satunya makna Al-Quran yang sebenarnya, satu-satunya tugas subjek hanya untuk menganalisis kebenaran yang tidak berubah tersebut (Navid Kermani, 1999).

\section{Penutup}

Upaya Abu Zayd untuk mendefinisikan kembali peran sosial agama, kritik terhadap instrumentalisasi politik, dan upayanya untuk menekankan individulisme dan pengalaman subjektif seseorang dalam beribadah, perenenungan dan membaca ulang kitab suci, semua menghubungkannya dengan pemikir reformis seperti Mohammed Arkoun, orang Aljazair yang tinggal dan mengajar di Paris, Abdolkarim Soroush dari Iran, dan beberapa penulis Muslim kontemporer lainnya. Dengan memfokuskan dalam konteks sosial dan intelektual yang bervariasi secara luas, pemikir semacam itu menekankan fakta bahwa Al-Qur'an menyediakan pedoman etika umum, namun tidak memiliki jawaban atas semua masalah kemanusiaan dan sosial. Sebelumnya para pemikir reformis Islam ini juga membela demokrasi dan menghormati hak asasi manusia dengan alasan bahwa prinsip tersebut didukung oleh Islam. Sebaliknya, kaum intelektual kontemporer berpendapat bahwa kita seharusnya tidak menggunakan Islam untuk mendukung prinsip-prinsip seperti itu, sebaiknya kita menegakkannya atas dasar dasar akal pikikran dan kemauan sosial Islam yang kita miliki, Abu Zayd berpendapat sebagai sebuah agama, Islam bertindak sebagai kerangka acuan, tapi dia tidak dapat mempengaruhi manusia hanya dengan mengacu pada Islam. Lagipula, banyak pencapaian manusia yang tak terbantahkan dihasilkan dari luar agama. Dengan menolak instrumentalisasi agama terlepas dari motivasi yang dimiliki, intelektualitas semacam itu telah mengatasi suatu hambatan dasar dalam pemikiran reformis Muslim. Generasi sebelumnya merasa diwajibkan menafsirkan teks sumber religius yang menantang modernisme pengertian hak asasi manusia dan masyarakat sampai pada titik di mana mereka menyelesaikan kontradiksi antara keduanya. Abu Zayd dan Soroush, hanya dua pemikir kontemporer tersebut, yang menerima kontradiksi sebagai persoalan fakta tapi mempertimbangkan ketidakrelevansian hal tersebut karena tidak mempengaruhi esensi agama.

Untuk menyimpulkan, aspek yang paling menarik dari karya Abu Zayd tampaknya menjadi upayanya - berdasarkan pengetahuan mendalam tentang ilmu agama tradisional - untuk mengadaptasi temuan-temuan lingusitik modern dan teori hermeneutika filosofis dalam menganalisis Al-Quran dan teologi Islam. Dengan melakukan hal tersebut, dia melanjutkan sebuah proyek yang menjanjikan dalam 
penafsiran sastra yang diprakarsai oleh al-Khuli, yang memandang Al Qur'an sebagai teks yang disusun secara puitis, dan sebagai sebuah monumen sastra, bukan daftar penghakiman atau sekedar teks hukum. Seperti al-Khuli dan rekan langsungnya, Abu Zayd memiliki pengetahuan mendalam tentang tradisi Islam. Namun, dia melakukan upaya yang lebih jelas lagi dengan menerapkan temuan sains linguistik modern dan teori hermeneutika filosofis untuk mempelajari Al-Quran dan teologi Islam Ini telah menghasilkan kesejajaran yang luar biasa dalam upaya bersama dalam studi Islam-Barat kontemporer untuk mempelajari Al-Quran sebagai teks sastra. Fakta bahwa Abu Zayd bukan satu-satunya orang yang menyuarakan hal tersebut namun memiliki rekan sejawat Muslim kontemporer yang memiliki pandangan serupa menunjukkan bahwa bidang studi Alquran di dunia Islam semakin beragam dan reflektif.

\section{Daftar Pustaka}

Agarama, Hussein Ali. Questioning Secularism: Islam, Sovereignty, and the Rule of Law in Modern Egypt. (Chicago : University of Chicago Press, 2012)

al-Suyuti, Jalal ai-Din. al-Itqanfi 'ulum al-Qur'an, cd. Ahmad Sa'd 'Ali (Cairo: Daar el-Fikr AlArabiyah, 1951)

al-Zarkashi, Badr ai-Din Muhammad ibn 'Abdullah, al-Burhanji 'ulum al-Qur'an, (Beirut: Daar elKutub Al-Alamiyah, 1988)

Farouki, Suha Taji. Modern Muslim Intellectuals and the Qur'an. (Oxford : Oxford University Press, 2004)

Harb, Ali, Naqd al-nass (Beirut: Daar el-Kutub Al-Islamiyah, 1993)

Izutsu, Toshihko God and Man in the Koran: Semantics of the Koranic Weltanschauung (Tokyo, 1964; repr. New York, 1980) 